\title{
Г.Г. Исаев
}

\section{Истоки ближневосточного конфликта: образование государства Израиль}

Понятия «ближневосточный конфликт» и «ближневосточное урегулирование», существующие в современных исторической и политической науках, приняты для обозначения именно арабо-израильского конфликта и попыток его разрешения. Арабо-израильский конфликт стал причиной нескольких широкомасштабных войн, породил ряд серьезных проблем, став главным источником нестабильности на Ближнем Востоке. До сих пор большинство арабских стран не имеют не только дипломатических связей с Израилем, но и мирных договоренностей, предполагающих взаимное признание в существующих границах.

В контексте биполярной системы международных отношений, просуществовавшей вплоть до конца 80-х гг. XX в., арабо-израильский конфликт стал одной из горячих зон «холодной войны» между США и СССР, которые, поддерживая разные стороны, пытались обеспечить свое присутствие в стратегически важном регионе. США и СССР, с одной стороны, оказывали помощь в развитии экономики и промышленности стран региона, с другой - активно снабжали противоборствующие стороны техникой и вооружениями, создавая основу для военной составной конфликта. На наш взгляд, объективная оценка роли сверхдержав в ближневосточном конфликте заключается в понимании того факта, что их политика на Ближнем Востоке преследовала прагматичные цели и часто была далека от официально провозглашаемой цели «урегулирования» ближневосточного конфликта.

Отношения отдельных арабских или неарабских стран региона с Израилем строятся на разных принципах - от официальных мирных отношений и экономического сотрудничества (Египет, Иордания, Тунис, Турция) до открытой враждебности с постоянной угрозой военного столкновения (Иран, Сирия, Ливан). Основными проблемами в двусторонних отношениях являются нерешенные территориальные вопросы: Израиль до сих пор удерживает некоторые территории арабских 
стран, и поддержка арабскими странами военизированных группировок на территории Израиля. Однако на протяжении всей истории арабо-израильских отношений самым серьезным остается вопрос положения палестинцев на оккупируемых территориях и палестинских беженцев вне Израиля.

Палестино-израильский конфликт, связанный с борьбой палестинского народа за право самоопределения, должен быть отдельно выделен и рассмотрен в рамках арабо-израильского конфликта.

Говоря об истоках арабо-израильского конфликта, необходимо затронуть вопрос еврейской колонизации Палестины. История еврейства в Новое время в первую очередь связана с историей Старого и Нового Света - например, к началу XIX столетия около 90\% евреев проживало в Европе [Лакер, 2000, с. 17]. В этот же период еврейское население Палестины насчитывало всего лишь несколько тысяч человек, проживавших в четырех городах, а именно - в Иерусалиме, Сафеде (Цфате), Тиверии и Хевроне [Очерки по истории..., 1972]. Небольшие группы поселенцев приезжали в Палестину, но в целом до конца XIX в. условий для создания еврейского очага не было - во многом по причине отсутствия концепции. Это была эпоха «старинного мессианского» и мифического сионизма, как обозначил ее американский исследователь Вальтер Лакер. В конце XIX в. под влиянием политических и социальных процессов в Европе возникает политический сионизм, который ставит своей задачей создание еврейского государства. Теодор Герцль, как один из основателей сионизма, пошел гораздо дальше простых деклараций о необходимости создания еврейского очага в Палестине, создав еврейское национальное движение, главной целью которого было обретение государственности. В конце XIX в. в Палестину уже каждый месяц иммигрировали несколько десятков евреев.

История сионистского движения заслуживает отдельного исследования. В контексте заявленной темы следует обратить внимание на подход сионистов к коренному населению Палестины - арабам. Вопрос «кто истинно коренной житель Палестины» до сих пор является краеугольным в споре между евреями и арабами. С одной стороны, евреи ссылаются на древнюю историю еврейского народа, связанную исключительно с Палестиной, с другой, арабы говорят о более чем тысячелетней истории пребывания на Святой Земле. В мире не существует примеров и юридических прецедентов, которые бы способствовали решению подобных споров. Вопрос взаимоотношений с арабами Палестины поднимался неоднократно лидерами сионистского движения. Некоторые сионисты игнорировали наличие арабского населения, выдвигая лозунг «землю без народа - народу без земли», такие авторы, как Хаим Хисин (известный публицист и журналист), критиковали политику еврейских колонистов по отношении к арабскому населению. С 
самого начала сионисты отстаивали создание в Палестине именно еврейского национального государства, идея арабо-еврейской солидарности была чужда большинству переселенцев. Евреи-сионисты являлись носителями европейской культуры и считали себя оплотом цивилизованного прогрессивного Запада на отсталом варварском Востоке. Арабские крестьяне были для них не товарищами и союзниками, а отсталыми дикарями, помехой на пути национальной еврейской государственности. Так, сионизм оказался одновременно и национальноосвободительной идеей и колонизаторским проектом [Инсаров, Магид, 2006]. Кроме Хаима Хисина, за большее уважение к местному населению ради создания добрососедских отношений выступал известный своей полемикой с Герцлем Ахад Гаам, также критиковавший поведение еврейских поселенцев в Палестине.

В 1917 г. в Великобритании была опубликована «декларация Бальфура», которая представляла собой письмо министра иностранных дел Великобритании барону Уотеру Ротшильду, представителю британской еврейской общины. Текст письма сводился к тому, что Великобритания гарантировала евреям государство в Палестине. Собственно, британцы вели двойную игру - в 1915-1916 гг. велась активная переписка между английским Верховным комиссаром в Египте сэром Генри Мак-Магоном и эмиром Мекки шерифом Хусейном, где поднимался вопрос будущего Палестины, которую англичане обещали предоставить арабам.

24 июля 1922 г. на международной конференции в Сан-Ремо Великобритания получает мандат Лиги Наций на управление Палестиной. Согласно мандату Великобритания обязалась способствовать иммиграции евреев и создать такие политические, административные и хозяйственные условия, которые обеспечили бы установление еврейского национального дома в Палестине. Однако к концу 30-х гг. XX в. позиция Великобритании претерпела серьезные изменения. В 1930-е гг. на территории подмандатной Палестины имели место столкновения между арабами и евреями, а также вооруженные выступления палестинцев против британской колониальной администрации (особенно остро в годы «Палестинской революции» 1936-1939 гг.).

Находившаяся в Палестине в конце ноября 1936 - начале 1937 г. королевская комиссия лорда Пила сделала неутешительные для англичан выводы - мандатный режим не в силах решить усугубляющийся конфликт между палестинцами и евреями. В своих выводах комиссия предлагала созвать конференцию с участием руководства еврейских и арабских общин в Палестине. «Сент-Джеймская» конференция, в которой приняли участие как арабы, так и евреи, собралась в Лондоне в феврале 1939 г., а в мае был опубликован отчет британского министра колоний Малькома Макдональда парламенту Великобритании, вошедший в историю как «Белая книга» Макдональда. Фактически «Белая книга» стала ревизией «Декларации Бальфура» - в ней содержались 
предложения создать в Палестине через 10 лет независимое государство с арабским большинством, разрешить въезд в Палестину в ближайшие 5 лет 75 тысячам еврейских поселенцев, ограничить покупку земли евреями. Сионисты восприняли «Белую книгу» крайне негативно. Против британской администрации Палестины была развернута активная террористическая деятельность, не прекращавшаяся в течение всей Второй мировой войны.

В 1942 г. небольшая группа сионистских экстремистов под предводительством Абрахама Штерна стала известна тем, что организовала в районе Тель-Авива ряд политических убийств и грабежей. На следующий год стало известно о широком заговоре, в котором была замешана «Хагана» (нелегальное военное формирование, контролируемое Еврейским агентством), с целью похищения оружия и боеприпасов у английских вооруженных сил на Ближнем Востоке. В августе 1944 г. Верховный комиссар едва не погиб при нападении из засады за чертой Иерусалима. Три месяца спустя, 6 ноября, английский государственный министр на Ближнем Востоке (лорд Мойн) был убит в Каире двумя членами группы Штерна. Еще одна нелегальная еврейская организация «Иргун цеваи леуми» - нанесла в течение 1944 г. большой ущерб государственному имуществу... [British Government..., 1947, p. 32].

Ограничения на иммиграцию и политика британской администрации, тем не менее, по сути не помешали росту количества еврейских поселенцев в Палестине. Если после Первой мировой войны евреи составляли менее одной десятой населения Палестины, то в 1947 г. они уже составляли почти треть. Интересно в связи с этим привести слова известного британского историка и культуролога Арнольда Тойнби, работавшего в ту пору в министерстве иностранных дел Великобритании: «Причина существования на сегодняшний день государства Израиль и наличия 1,5 млн. палестинских арабов-беженцев заключается в том, что на протяжении тридцати лет еврейская иммиграция с помощью английской военной мощи навязывалась палестинским арабам до тех пор, пока иммигранты не стали достаточно многочисленны и достаточно хорошо вооружены, чтобы быть в состоянии позаботиться о себе с помощью своих танков и самолетов» [John, Hadawi, 1972, p. XIV-XV].

Англичане в условиях войны с Германией опасались, что арабы, разочарованные Великобританией, будут поддерживать фашистов. Поэтому в конце 1930-х гг. англичане инициируют появление проарабской «Белой книги», а высшие политические деятели заявляют о своем принципиальном согласии для создания в перспективе единого арабского государства.

Британское двурушничество не устраивало сионистов, которые ожидали более активной поддержки со стороны Великобритании в вопросе создания еврейского государства. Сионисты стремились заручиться поддержкой Соединенных Штатов взамен поддержки, которой 
они лишились со стороны Великобритании. В мае 1942 г. исполком Еврейского агентства на своем заседании в Нью-Йорке официально огласил то, что известно как «программа Билтмора» - долгосрочную цель создания еврейского государства в Палестине путем неограниченной иммиграции [Истоки и история проблемы Палестины...].

После окончания Второй мировой войны вопрос о прекращении британского мандата на Палестину был поднят в рамках ООН. Поводом стали необходимость решения вопроса еврейского самоопределения и неспособность Великобритании обеспечить мир на Святой земле. Другими причинами были ослабление Великобритании после войны, распад британской колониальной системы, а также попытки США и СССР за счет Великобритании расширить сферы своего влияния в восточном Средиземноморье. Европейская и американская общественность ратовала за решение «еврейского вопроса» и создания независимого еврейского государства, которое сионисты видели только на территории Палестины. Попытки британской администрации договориться с арабами и евреями и решить вопрос без участия $\mathrm{OOH}$ не привели к успеху английские предложения не удовлетворили ни сионистов, ни арабов. 14 февраля 1947 г. вопрос будущего Палестины был передан на рассмотрение $\mathrm{OOH}$.

Принятие решения по палестинскому вопросу было возложено на Специальную комиссию ООН по Палестине (UNSCOP), созданную 15 мая 1947 г., куда вошли представители следующих государств: Австралии, Канады, Чехословакии, Гватемалы, Индии, Ирана, Нидерландов, Перу, Швеции, Уругвая и Югославии. 15 июня комиссия прибыла в Палестину для изучения положения на месте. 1 сентября Специальная комиссия представила в ООН свой доклад, в котором содержался ряд рекомендаций, принятых комиссией единогласно: отмена мандата на Палестину, предоставление Палестине независимости и др. Одновременно было представлено два плана будущего устройства Палестины, условно обозначаемые в литературе как «план большинства» и «план меньшинства».

«План большинства», одобренный представителями Канады, Чехословакии, Гватемалы, Голландии, Перу, Швеции и Уругвая, предусматривал раздел Палестины на два независимых государства - арабское и еврейское. Иерусалим переходил под опеку ООН. В переходный период, который должен был продлиться два года, управление Палестиной осуществлялось Великобританией под наблюдением ООН.

«План меньшинства», одобренный Югославией, Индией и Ираном, предполагал создание единого федеративного государства, состоящего из арабского и еврейского штатов со столицей в Иерусалиме.

Однако в судьбе Палестины решающее значение имели позиции США и СССР. Министр иностранных дел СССР Молотов послал указание своему заместителю Вышинскому в Нью-Йорк «...не возражать про- 
тив мнения большинства по вопросу о разделе Палестины...» [Телеграмма министра..., 2000, с. 252]. Таким образом Советский Союз подтверждал свое согласие с созданием двух государств на территории Палестины. Позиция СССР в этом вопросе совпадала с позицией США. Арабские государства восприняли этот факт отрицательно. Еще недавно СССР поддерживал Египет и Индонезийскую республику и проводил политику «выдавливания» империалистов с Ближнего Востока. Но позиция СССР по палестинскому вопросу разочаровала лидеров арабского национально-освободительного движения.

Некоторые советские дипломаты высказывали другие мнения: например, в письме поверенного в Ираке А.Ф. Султанова содержится анализ ситуации и перечень негативных последствий позиции СССР по «палестинскому вопросу», среди которых опасения, что такая политика «поможет сколотить антисоветский мусульманский блок из стран Арабской лиги, Турции, Ирана и Пакистана... [...] Арабские правительства, «разуверенные в поддержке СССР и поощряемые англосаксами, используют это обстоятельство для прямого вступления с последними в явно антисоветское соглашение о дальнейшем открытом предоставлении баз и стратегических ресурсов на случай войны против нас» [Резюме письма..., 2000, с. 265].

Тем не менее СССР согласился с вариантом создания двух государств на территории Палестины: советское руководство надеялось, что еврейское государство сможет быть дружественным СССР - имелись в виду большое количество выходцев из России и благодарность евреев Советскому Союзу за освобождение Европы от фашизма.

27 ноября 1947 г. на Генеральной Ассамблее ООН была принята резолюция № 181 о разделении Палестины на еврейское и арабское государства. 33 государства проголосовали «за», 13 - «против», 10 воздержались.

Еврейскому государству отводилось около 56\% территории Палестины, арабскому - 43\% [The United Nations Partition Plan, 2006]. На тот момент в Палестине проживало около 650 тыс. евреев и 1200 тыс. арабов. При этом еврейское государство получало территорию, экономически более развитую [United Nations Special Committee on Palestine, 1947], имеющую выходы к Средиземному и Красному морям.

В кулуарных беседах представители сионистских организаций выражали свой взгляд на будущее устройство еврейского государства и на его вероятную позицию в международных отношениях. Так, в основе международной политики должен был быть нейтралитет наподобие швейцарского. «Еврейское государство стало фактическим в результате позиции главным образом США и СССР... В США имеется 5 млн. евреев, в СССР - 3 млн. евреев. Новое еврейское государство не хочет держать ориентацию на какую-либо определенную страну, поэтому наиболее правильным внешнеполитическим курсом для нового еврейского госу- 
дарства был бы нейтралитет и ориентация на ООН» [Запись беседы временного поверенного..., 2000, с. 277]. Еще до создания государства Израиль приоритет в будущем экономическом сотрудничестве отдавался США. Это касалось закупок вооружения, оборудования и прочих необходимых предметов снабжения. Их предполагалось закупать главным образом в США, что должно было определить позицию еврейского государства в биполярном мире, создание которого уже шло полным ходом.

Следует отметить, что позиция США по палестинскому вопросу не отличалась последовательностью. Это было связано с внутриполитическими процессами: с одной стороны, американские нефтедобывающие компании не разделяли просионистскую позицию своей страны, чреватую потерей доверия арабских нефтеэкспортирующих государств. С другой стороны, еврейское лобби призывало к поддержке своих соплеменников в Палестине. Следует отметить, что фактор «советско-еврейского секретного соглашения», якобы имевшего место, играл важную роль и активно использовался определенными кругами. C помощью него стимулировалось негативное отношение арабских стран к СССР, что заставляло сионистские круги все чаще обращаться к США из опасения быть уличенными в просоветской ориентации.

Вместе с тем определенный поворот в позиции США произошел, что проявилось в отказе от продажи оружия еврейским организациям и отказе от поддержки решения Генеральной ассамблеи ООН по разделу Палестины. После ухудшения ситуации в Палестине в марте 1948 г. постоянным членам Совета Безопасности ООН было поручено провести консультации и дать рекомендации относительно мер по осуществлению резолюции № 181 Генеральной Ассамблеи ООН от 29 ноября 1947 г. о разделе Палестины.

США представили документ, констатировавший невозможность осуществления резолюции о разделе без применения силы. США выступили с предложением временной опеки со стороны $\mathrm{OOH}$, что было с гневом отвергнуто сионистами, особо радикальные даже обвинили США в империалистических притязаниях и предательстве дела евреев. Арабская сторона крайне позитивно восприняла эту информацию.

Синдром страха возникновения еврейского государства на территории Палестины оказал консолидирующее для арабского мира значение, но все же в недостаточной степени, чтобы организовать эффективное противодействие. В общих чертах позиция палестинских арабов, поддерживаемая соседями, сводилась к двум основным пунктам: прекращение иммиграции евреев в Палестину, создание единого и неделимого палестинского государства с многонациональным правительством на базе пропорционального представительства. Полностью противоположным было мнение сионистов, которые по арабскому варианту пропорционального представительства оказались бы на пози- 
циях меньшинства, (составляя в то время не более трети населения Палестины), к тому же прекращение иммиграции не позволяло изменить существующие пропорции.

Все чаще вспыхивали вооруженные конфликты между арабами и евреями, приводившие к большим жертвам с обеих сторон. Английский флот блокировал порты на берегу Средиземного моря и препятствовал ввозу оружия. США, как было сказано выше, ввели эмбарго на поставку оружия. Тем не менее оружие еврейские поселенцы получали нелегальными каналами. Арабские страны снабжали английским оружием палестинцев. Крупные отряды добровольцев из Ирака, Трансиордании, Сирии, Ливана приехали в Палестину для борьбы с сионистами. Согласно решению ООН, срок действия английского мандата истекал 15 мая 1948 г. Поэтому англичане стремились использовать время для решения собственных задач, среди которых основной являлось сохранение своего влияния в Палестине. Одним из вариантов стало присоединение арабской части Палестины к Трансиордании. Английская администрация инспирировала арабо-еврейские столкновения с целью срыва решения $\mathrm{OOH}$ о разделе Палестины. Подобные утверждения сложно доказать или опровергнуть, однако можно констатировать пассивность английской администрации и ее попустительство, приведшее к обострению ситуации в Палестине. Англия официально заявляла о своей нейтральной позиции и стремлении обеспечить мир в Палестине. Однако с момента решения $\mathrm{OOH}$ о разделе Палестины вплоть до окончания английского мандата на территории Палестины развернулась гражданская война.

Одним из самых жестоких эпизодов этой войны была резня в арабской деревне Дейр-Ясин 9 апреля 1948 г., осуществленная руками боевиков еврейских иррегулярных отрядов Лехи и Иргун. В ходе штурма деревни с последующей расправой над жителями погибло 254 палестинца [New York Times, 3.04.1948; см. также: Milstein, 1991, p. 255-276]. Это событие вызвало серьезный резонанс, спровоцировав массовый исход арабов из Палестины, ответную жестокость со стороны арабов (уничтожение еврейского медицинского конвоя 13 апреля 1948 г.), и стало одним из трагических символов для палестинского сопротивления.

15 мая 1948 г. армии пяти арабских стран, стремясь не допустить появления еврейского государства, вступили на территорию Палестины. Началась первая арабо-израильская война, которая в Израиле получила название «Войны за независимость», в арабских странах - «Палестинской войны». Несмотря на то, что в войне приняло участие несколько арабских стран, их вооруженные силы, за исключением иорданских войск, представляли собой неорганизованные и плохо вооруженные формирования. Численность их была невелика: Египет 5500 чел, Сирия - 6000 чел., Ирак - 4500 чел., Ливан - 1000 чел, Трансиордания - ок. 6000 чел. 
На фоне боевых действий, подтвердивших опасения скептиков по вопросу разделения Палестины, посредник ООН по палестинскому вопросу граф Ф. Бернадотт (представитель Швеции) в июне 1948 г. называет резолюцию ООН от 29 ноября 1947 г. неудачной и предлагает ее пересмотр. План Бернадотта предполагал восстановление Палестины в границах 1922 г. (до выделения Трансиордании) в качестве унитарного государственного образования и выделение двух государств - еврейского и арабского - как членов единого союза. Негев отошел бы к арабам, Галилея - Израилю. Палестинские беженцы возвращались домой и получали обратно свое имущество. Иерусалим, согласно плану, вошел бы в состав арабского государства. Порт Хайфа и аэропорт Лодд становились свободными зонами. Предложение отвергли обе стороны. Евреи и так уже контролировали Западную Галилею, отторжение Негева означало потерю 2/3 территории Израиля. Вариант слияния Трансиордании с арабской частью Палестины, который так-же предлагал Бернадотт, означал переход ее под контроль англичан, которые поддерживали тесные отношения с королем Трансиордании Абдаллой. Сирия, Египет и Ирак не хотели усиления Трансиордании за счет Палестины (с Негевом). Сионисты в принципе не были против этого варианта, надеясь, что смогут в итоге договориться с Абдаллой об оставлении Израилю Западной Галилеи и Негева.

Развернутые предложения посредника ООН были направлены им Совету Безопасности 16 сентября 1948 г., а 20 сентября включены в повестку дня сессии Генеральной Ассамблеи. План Бернадотта, измененный и дополненный, сводился теперь к следующим пунктам: подтвердить существование государства Израиль, призвать стороны решить споры мирными средствами, подтвердить право арабских беженцев на возвращение в свои дома, определить статус Иерусалима.

Англия обещала признать Израиль де-юре в случае принятия плана Бернадотта. Представители США также обещали признание деюре и предоставление займа в случае согласия еврейской стороны. Сам Бернадотт был убит еврейскими террористами 17 сентября 1948 г. Причины неприятия плана Бернадотта Израилем заключались в следующем: потеря Негева отрезала остальную часть Израиля от залива Аккаба и Мертвого моря, международный статус Иерусалима Израиль устраивал, но еврейская часть должна была относиться к Израилю и быть связана с остальной частью страны широким коридором. Однако действия израильской армии вносили собственные коррективы, итогом войны стало поражение арабских армий.

СБ ООН, пытаясь остановить боевые действия, принял две резолюции 4 и 13 ноября 1948 г., в которых потребовал прекращения боевых действий от конфликтующих сторон. В первой половине 1949 г. арабские страны и Израиль садятся за стол переговоров на о. Родос с целью 
заключить перемирие. 24 февраля 1949 г. Израиль подписывает соглашение о прекращении огня с Египтом, 23 марта - с Ливаном, 3 апреля с Иорданией и 20 июля - с Сирией.

Итоги войны были неутешительны для арабов. Вопреки решению $\mathrm{OOH}$, арабское государство не было создано на территории Палестины Израиль оккупировал 77\% ее территории, равно как и большую часть Иерусалима, остальное захватили Иордания и Египет. В результате войны территория Израиля увеличилась на 46,4\%. Поражение арабских армий в первой арабо-израильской войне стало следствием не только их экономической отсталости и военной несостоятельности, но и отсутствия единой политики по палестинскому вопросу. Одну из причин поражения арабы видели в действиях иорданцев и короля Абдаллы, который был больше озабочен вопросом расширения территории собственного государства за счет Палестины, чем судьбой палестинского народа. (Именно в отместку за свое «предательство» дела Палестины иорданский король был застрелен членом террористической палестинской организации на пороге мечети Аль-Акса в арабской части Иерусалима 20 июля 1951 г.)

Разобщенность и отсутствие единства в действиях арабских стран - как на стратегическом, так и на тактическом уровне - привели к их поражению. В результате первичные цели, не допустить образования Израиля, провалились, арабские войска потерпели фиаско, а Израиль не только не был «стерт с карты», но увеличил свою территорию.

Среди наиболее значимых с геополитической точки зрения территорий, которыми завладел Израиль, были:

западная часть Иерусалима (при том, что резолюция ООН предлагала интернационализацию, то есть оставление, Иерусалима под международным контролем);

Яффо - по преимуществу арабский пригород Тель-Авива (по плану ООН должен был остаться арабским анклавом, связанным с будущим арабским государством);

на севере - арабская часть (примерно треть) Галилеи;

на юге - Беэр-Шева и ее окрестности;

на юго-западе - полоса Ашдод-Ашкелон;

в центре - район Лод-Рамле [Зеев, 2001].

Одной из самых серьезных проблем, которую породила первая арабо-израильская война, стала проблема палестинских беженцев. Около 800 тыс. человек (по данным ООН - 711 тыс.) покинули свои дома и вынуждены были искать убежища в соседних арабских странах. Массовый исход палестинцев со своих земель получил название «альНакба» (катастрофа).

В резолюции ООН о разделе Палестины было сказано: «В еврейском государстве не допускается экспроприация арабских земель, кроме как на общественные нужды... Во всех случаях экспроприации 
предварительно должна быть выплачена полная компенсация в размере, установленном Верховным судом». Но уже в декабре 1948 г. Временное правительство выпустило первые постановления о покинутых землях и брошенном имуществе, целью которых было предотвратить возвращение недвижимости их хозяевам - арабам, оставившим страну во время или сразу же после войны 1948 г. Поначалу казалось, что эти постановления относятся только к той, большей части арабского населения, которая бежала через линии фронтов в соседние арабские страны. Такова была цель закона, принятого Кнесетом первого созыва в 1950 г. Он уполномочил правительственного опекуна продать покинутые арабские земли и брошенные дома Земельному управлению, которое в свою очередь, имело право сдать землю и другое недвижимое имущество в аренду различным еврейским поселениям или, если речь шла о городских зданиях, отдельным лицам.

Однако в течение двух лет, прошедших с момента образования государства, выяснилось, что акты о брошенном имуществе санкционируют также конфискацию около 40\% земли, принадлежащей арабским жителям Израиля. Арабы, владевшие собственностью в Акко, Лоде, Рамле, Иерусалиме, считались оставившими свое имущество даже в том случае, если они поселились в окрестных деревнях [Сакер, 1994, c. 45-60].

Трансиордания аннексирует территорию Западного берега реки Иордан - поглотив то, что должно было стать частью арабского государства. 23 апреля 1950 г. специально созванный парламент официально провозгласил единство Трансиордании и восточных областей Палестины в составе Иорданского хашимитского королевства [Современная Иордания, 1964, с. 102].

Военные успехи Израиля способствовали его признанию со стороны многих стран мира. Наметились улучшения в отношениях с США и даже с Великобританией. Тем не менее позиция израильского правительства официально продолжала оставаться «нейтральной» - в контексте разделения мира на два лагеря.

Страны Восточной Европы согласились на частичную репатриацию евреев в Израиль. Там, где еврейские общины составляли небольшой процент - Югославия, Польша, Болгария - проблем с репатриацией не было. Венгрия и Румыния, с самыми крупными еврейскими диаспорами (200 и 350 тыс. чел.), относились к эмиграции евреев негативно по причине опасения, что их отъезд может причинить вред этим странам.

Вопрос репатриации для Израиля имел большое значение. Планировалось интенсивное заселение Негева и других стратегических территорий. Все чаще поднимался вопрос о возможности переезда советских евреев в Израиль. Советское правительство разграничило вопрос поддержки политики Израиля в ООН и в международной политике и вопрос репатриации за счет советских граждан еврейской нацио- 
нальности. Последний вопрос и являлся камнем преткновения в советско-израильских отношениях.

9 декабря 1949 г. Генеральной Ассамблеей была принята резолюция, подтвердившая принципы решения Генеральной Ассамблеи от 29 ноября 1947 г. о выделении Иерусалима в качестве «corpus separatum» под управлением ООН. Совету ООН по Опеке поручалось доработать Статут Иерусалима и принять меры для введения его в действие. СССР, Франция, арабские и латиноамериканские страны голосовали за резолюцию; Израиль, США, Великобритания, Швеция, Дания, Уругвай и Югославия - против.

В 1949 г. Великобритания и США инициировали процессы создания военно-политической организации по типу НАТО на Ближнем Востоке. Несмотря на то, что арабские страны вряд ли согласились бы войти в блок вместе с Израилем, израильское правительство использовало свой отказ от участия в каких-либо военных блоках для того, чтобы подчеркнуть свою нейтральную позицию. Отказ от размещения на территории Израиля военных баз Великобритании и США позитивно воспринимался Советским Союзом. Можно сказать, что Израиль своим отказом от вступления в военно-политические блоки одним из первых заявил о собственном «неприсоединении» на несколько лет раньше создания «Движения неприсоединения».

Однако в контексте усиливающихся противоречий между СССР и США, сопровождавшихся борьбой за сферы влияния, сохранение «нейтральной» позиция Израиля, созданного при непосредственном участии Советского Союза и Соединенных Штатов, оказалось невозможным. В период с 1949 до 1953 г. советско-израильские отношения ухудшились, что сопровождалось острой полемикой в прессе и в беседах представителей МИД обеих стран. В ходе встречи министра иностранных дел Израиля М. Шаретта с министром иностранных дел СССР А.Я. Вышинским, состоявшейся 6 января 1952 г. в Париже, снова обсуждался вопрос иммиграции советских евреев в Израиль. Вышинский отметил проамериканскую позицию Израиля по ряду важных вопросов в ООН. Шаретт в свою очередь возразил, что без финансовой помощи США Израиль не мог бы встать на ноги и обеспечить репатриацию евреев со всего мира. Вышинский сказал, что СССР на определенном этапе своего развития находился в таком же положении и единственным выходом казалась раздача концессий иностранцам и потеря независимости, но страна смогла справиться своими силами. Полемика между лидерами министерств иностранных дел двух стран носила весьма острый характер, что отражало возросшее напряжение в советско-израильских отношениях.

Наверное, один из самых риторических вопросов был озвучен Шареттом: «Мы заинтересованы поддерживать равновесие в нашей международной позиции, но СССР не помогает нам добиться этого. 
У американцев есть сильный козырь, которым вроде бы располагает и Советский Союз, но Москва почему-то совсем его не использует. В результате получается, что в этом плане перевес на американской стороне. Этот козырь - свободные связи между евреями диаспоры и Израилем» [Запись беседы министра иностранных дел Израиля М. Шаретта..., 2000, c. 323].

СССР не мог согласиться на эмиграцию тысяч своих граждан, так как на официальном уровне национальный вопрос был решен - ни один народ не мог бы искать лучшей жизни, чем в Советском Союзе. Признание за евреями права возвращения на родину означало бы признание сионизма - националистической идеологии, чуждой коммунистической и интернациональной. СССР признал права евреев (ленинский тезис права нации на самоопределение) и сам выступал за репатриацию евреев из послевоенной Европы, где они не могли устроиться. Но в СССР евреи считались неотъемлемой частью многонационального советского общества, поэтому их отторжение воспринималось советским руководством негативно.

9 февраля 1953 г. на территории миссии СССР произошел взрыв бомбы, брошенной неизвестными террористами. В ноте протеста от имени правительства Советского Союза ответственность за террористический акт возлагалась на правительство Израиля и сообщалось о разрыве дипломатических отношений между государствами.

Факт разрыва советско-израильских отношений был положительно отмечен в арабских странах. Так, в Пакистане посланник Сирии Джават аль-Моурабет заявил временному поверенному в делах СССР в Пакистане Дорофееву, что если советское правительство восстановит отношения с Израилем, это «серьезно огорчит все население арабских стран» [Телеграмма Дорофеева..., 2000, с. 446]. После смерти Сталина советско-израильские отношения были восстановлены. Возвращения к теплым отношениям периода 1947-1948 гг. не произошло - этому мешали в первую очередь связи между Израилем и США. 


\section{Список литературы}

Сакер Г. М. История Израиля. Т. 3. Формирование израильской республики. Иерусалим, 1994.Запись беседы временного поверенного в делах СССР в США С.К. Царапкина с представителем Еврейского агентства для Палестины в Вашингтоне Э. Эпштейном. 18 декабря 1947 г. // Советско-израильские отношения: Сборник документов. Т. 1: 1941-1953, Кн. 1. M., 2000.

Запись беседы министра иностранных дел Израиля М. Шаретта с министром иностранных дел СССР А.Я. Вышинским. 6 января 1952 г. // Советско-израильские отношения: Сборник документов. Т. 1: 1941-1953, Кн. 2. М., 2000.

Зеев Г. Политические структуры государства Израиль. М., 2001.

Инсаров М., Магид М. Сионизм. К истории одного национально-освободительного движения. 2006 // http://www.intersol.co.il/

Истоки и история проблемы Палестины. 1917-1988 г2. // http://www.un.org

Лакер В. История сионизма. М., 2000.

Очерки по истории еврейского народа / Под ред. С. Эттингера. Тель-Авив, 1972.

Резюме письма временного поверенного в делах СССР в Ираке А.Ф. Султанова в Ближневосточный отдел МИД СССР. 5 ноября 1947 г. // Советско-израильские отношения: Сборник документов. Т. 1: 1941-1953, Кн. 1. М., 2000.

Современная Иордания / Под ред. Е.А. Лебедева. М., 1964.

Справка Отдела стран Ближнего и Среднего Востока МИД СССР «0 попытках Израиля восстановить дипломатические отношения с СССР». 18 мая 1953 г. // Советско-израильские отношения: Сборник документов. Т. 1: 1941-1953, Кн. 2. М., 2000.

Телеграмма министра иностранных дел СССР В.М. Молотова заместителю министра иностранных дел СССР А.Я. Вышинскому, в Нью-Йорк 30 сентября 1947 г. // Советско-израильские отношения: Сборник документов. Т. 1: 1941-1953. Кн. 1. М., 2000.

British Government, The Political History of Palestine (Memorandum to the United Nations Special Committee on Palestine). Jerusalem, 1947.

Milstein Uri. The War of Independence. Vol. IV: Out of Crisis Came Decision. Tel-Aviv, 1991. New York Times. 13.04.1948.

John R., Hadawi S. The Palestine Diary. Vol. I (1914-1945) N.Y., 1972.

The United Nations Partition Plan. 2006 // http://www.merip.org/

United Nations Special Committee on Palestine, Recommendations to the General Assembly, A/364, 3 September 1947. Pt. I. Plan of partition with economic union justification // http://www.mideastweb.org 